\title{
The practice of plastic surgery in emergency trauma surgery: a retrospective glance at 10,732 patients
}

\author{
Plastik cerrahinin acil travma cerrahisindeki yeri: \\ 10,732 hastaya retrospektif bir bakış
}

\author{
Semra HACIKERIM KARŞIDAĞ, ${ }^{1}$ Özay ÖZKAYA, ${ }^{2}$ Kemal UĞURLU,${ }^{1}$ Lütfü BAŞ ${ }^{1}$
}

\section{BACKGROUND}

The number of patients applying to the emergency Plastic and Reconstructive Surgery outpatient clinic varies considerably depending on the sociocultural profiles of societies. Due to the abundance of anatomic regions comprising the targets of this field of specialization, plastic surgery is continuously gaining in importance in emergency traumatology.

\section{METHODS}

In this study, 10,732 patients admitted to the outpatient clinic of Emergency Plastic Surgery in Şişli Etfal Training and Research Hospital were evaluated retrospectively regarding etiology, sex, age distribution, injury characteristics, and treatment.

\section{RESULTS}

While $64 \%$ of all patients had forearm and hand injuries, $28 \%$ had maxillofacial injuries, and $8 \%$ had tissue defects. There was a male: female ratio of $4: 1$, and the mean age of all patients was 22.9 years. The mean age of patients (males $81 \%$ ) admitted with upper extremity injuries was 22.3 years. Most of the upper extremity injuries were due to glassware cuts $(33 \%)$. The mean age of patients admitted with maxillofacial trauma was 23.2 years. Among the patients with head-and-neck injuries, the most frequent cause of trauma was traffic accidents (38\%).

\section{CONCLUSION}

Regarding the frequency and characteristics of the patients treated, we suggest that plastic surgery shows a progressively increasing significance and widening field of practice in emergency traumatology and, as no similar study currently exists, ours will contribute significantly to the literature.

Key Words: Emergency; plastic surgery; trauma surgery.

\section{$\boldsymbol{A M A C}$}

Acil plastik cerrahi polikliniğine başvuran hasta sayısı toplumların sosyokültürel özelliklerine bağlı olarak ciddi farklılıklar göstermektedir. Çalışma bölgesinin yaygınlığ nedeni ile de plastik cerrahinin acil travmatolojideki önemi giderek artmaktadır.

\section{GEREÇ VE YÖNTEM}

Bu çalışmada, 2000-2004 yılları arasında Şişli Etfal Eğitim ve Araştırma Hastanesi Acil Plastik Cerrahi polikliniğine başvuran 10,732 hastanın etyoloji, cinsiyet, yaş dağ1lımı, yaralanma özellikleri ve tedavileri retrospektif olarak değerlendirildi.

\section{BULGULAR}

Başvuran hastaların \%64'ünde ön kol ve el yaralanmala$\mathrm{r} 1, \% 28$ 'inde maksillofasyal yaralanma ve \%8'inde doku defektleri vardı. Hastalarda 4/1 oranında erkek baskınlığ 1 vardı, yaş ortalaması 22,9 idi. Üst ekstremite yaralanması ile başvuran hastaların \%81'i erkek ve yaş ortalamaları 22,3 olarak bulundu. Üst ekstremite yaralanması olan hastalarda en sik etyolojik neden, \%33 ile cam kesisi idi. Maksillofasyal travma nedeniyle başvuran hastaların yaş ortalaması 23,2 olarak saptandı. Baş-boyun yaralanması olan hastaların \%38'inde travma sebebi trafik kazası idi.

\section{SONUÇ}

Tedavi edilen hasta sıklığı ve özelliği göz önüne alındığında plastik cerrahinin acil travmatolojideki yeri ve öneminin her geçen gün artmakta olduğunu ve benzer bir çalışma olmadığı için bu çalışmanın literatüre katkısı olacağını düşünmekteyiz.

Anahtar Sözcükler: Acil; plastik cerrahi; travma cerrahisi.
1Department of Plastic Reconstructive and Aesthetic Surgery, Şişli Etfal Training and Research Hospital, Istanbul;

${ }^{2}$ Department of Plastic Reconstructive and Aesthetic Surgery, Yalova State Hospital, Yalova, Turkey.
${ }^{1}$ Șişli Etfal Eğitim ve Arastırma Hastanesi, Plastik Rekonstrüktif ve Estetik Cerrahi Kliniği, İstanbul;

${ }^{2}$ Yalova Devlet Hastanesi, 1. Plastik Rekonstrüktif ve Estetik Cerrahi Kliniği, Yalova. 
In the literature, few studies have focused on the role of plastic and reconstructive surgery in trauma centers. ${ }^{[1]}$ According to the organization of some hospitals, plastic and reconstructive surgery particularly provides closure of tissue defects, while in others, surgery in the upper extremities and the head-and-neck region is also intensively performed. Progresses in microsurgery and their adaptation to trauma surgery have contributed considerably to the increasing significance of plastic and reconstructive surgery in trauma surgery. In two studies done in Israel, it was stressed that plastic surgery has an important role in large-scale injuries related to terrorist attacks. ${ }^{[2,3]}$ In addition, a study was published reporting the role of plastic surgery in repair of tissue defects following aircraft injuries. ${ }^{[4]} \mathrm{A}$ report from the United States stressed the critical importance of plastic surgery in emergency conditions requiring reconstructive interventions in all regions of the body. ${ }^{[1]}$

With a frequency of $38 \%$, upper extremity injuries constitute the largest patient group in emergency plastic surgery, followed in frequency by head-and-neck injuries $(25 \%)$, lower extremity injuries $(25 \%)$ and chest trauma $(12 \%) .{ }^{[1]}$ As the forearm and hand have their unique anatomies due to their complex functions, their injuries are also commonly combined injuries. ${ }^{[5]}$ Likewise, maxillofacial traumas vary regarding their etiologies and the fractured facial bones, and various treatment protocols are required depending on these factors.

Traumatic injuries significantly affect the patients socially, functionally and financially. Injuries within the field of practice of emergency plastic surgery, unless causing prominent hemodynamic instabilities as in cases of amputations and main artery injuries, are usually not life-threatening. However, injuries related to plastic surgery may result in considerable disability and loss of life quality. ${ }^{[6,7]}$

Our review of the literature revealed a few studies in which the issues within the field of interest of emergency plastic surgery, such as upper extremity surgery, head-and-neck traumas, and soft tissue traumas, were examined individually; however, no publication involved every field of practice of emergency plastic surgery. Therefore, retrospectively reviewing 10,732 patients admitted to the Emergency Plastic Surgery Department in Şişli Etfal Training and Research Hospital between 2000 and 2004, we aimed to construct a reference study stressing the significance of emergency plastic and reconstructive surgery in trauma centers.

\section{MATERIALS AND METHODS}

A total of 10,732 patients admitted to and treated in the Emergency Plastic Surgery Clinic in Şişli Etfal Training and Research Hospital between 2000 and 2004 were evaluated retrospectively regarding their age and sex distributions, etiology and type of injury, and treatment protocols. The age distributions of patients according to gender were investigated. The patients were evaluated in three major classes according to their cause of admission, namely upper extremity injuries, head-and-neck trauma and soft tissue injuries.

Upper extremity injuries: The age and sex distributions of 6,869 patients admitted with upper extremity injuries were studied, and the injuries were evaluated in 6 subgroups according to etiology, namely glassware cuts, falls, traffic accidents, household accidents, labor accidents, and miscellaneous (e.g., stabbing and bites). The distribution of etiology in the different age groups was investigated. Patients admitted with glassware cuts were classified as accidental injury and self-inflicted trauma during moments of aggression. In addition, injuries were studied in 4 groups according to the wound types, namely, isolated skin injuries, isolated tendon injuries, fractures-dislocations, and combined injuries (nerve, blood vessel, and tendon incisions, and bone pathologies). The pathologies developing with different etiologies were analyzed.

The patients were classified according to the treatment protocols as those treated in the emergency wards with local anesthesia and those treated in operation theaters under general anesthesia. Treatments in the emergency wards were classified as those accomplished under emergency conditions and those requiring secondary interventions under elective conditions. Likewise, patients treated in the operation theater were studied in groups such as combined injuries (e.g., tendon, nerve and vascular structure repair), replantation, fractures, open fasciotomy, major artery injuries, and miscellaneous.

Head-and-neck injuries: A total of 3005 patients admitted with head-and-neck trauma were evaluated regarding age and sex distributions. The patients were classified according to their cause of admission as traffic accidents, sports injuries, game injuries, injuries during daily activities, assaults, falls, and labor injuries. The distribution of the etiologic factors in age groups was studied. The head-and-neck injuries were evaluated in two groups according to the injured tissue contents as soft tissue injuries and bone fractures. Accompanying additional pathologies and systemic injuries were also investigated.

The cases with fractures were classified according to sex and etiology. Fractures were studied according to their anatomic locations as mandible, zygomatic bone, orbit base, and maxillary, nasal and frontal fractures. The mandibular fractures were classified further according to the fracture localization as symphysisparasymphysis, condylar, angular, trunk, ramus, and coronoid fractures. Likewise, maxillary fractures were 
classified as Le Fort I, II, III and sagittal fractures.

Patients admitted with head-and-neck injuries were studied in two groups according to time of treatment in the early and late periods, and factors influencing the time of treatment were investigated. Furthermore, treatment modalities of patients with fractures were examined.

Soft tissue injuries: Age and sex distributions of 858 patients admitted with soft tissue injuries were evaluated. The patients were studied via classification according to their etiologies, namely, falls, traffic accidents, gunshot wounds, burns, and infections. The distributions of etiologies by age groups were examined. The injury sites, the anatomic distributions of lower extremity defects, and the anatomic distributions of defects according to etiologies were studied. Coexistence of defects with fractures and the treatment modalities of fractures were investigated, and finally, the treatment modalities of defects located on the trunk and lower extremities were examined.

\section{RESULTS}

Between 2000 and 2004, a total of 10,732 patients were admitted under emergency conditions to the Emergency Plastic Surgery Clinic in Şişli Etfal Training and Research Hospital. Of the patients, 7902 $(73.6 \%)$ were males and $2830(26.4 \%)$ were females.

The mean age of the patients was 22.9 years (range: 2 months-93 years). Analysis of the age distribution of patients revealed that $64 \%$ of the patients were aged 11-35 years, with a male predominance. The second most common age group was $0-10$ years, with nearly equal gender distribution. We observed that the male predominance was most common among patients aged 21-35 years, while there was a progressive decline in male predominance with increasing age above 36 years. The age distributions in both sexes are displayed in Table 1.

The cause of admission was upper extremity injuries in 6869 patients (64\%), head-and-neck injuries in 3005 patients $(28 \%)$, and soft tissue traumas in 858 patients $(8 \%)$. While males with upper extremity injuries demonstrated a 4-fold predominance over females, the M:F ratio was approximately 1.5:1 among the cases of head-and-neck and soft tissue injuries (Table 2).

Upper extremity injuries: Of the 6869 patients admitted with upper extremity injuries, 5564 (81\%) were males and $1305(19 \%)$ were females (Table 2). The mean age of the patients was 22.3 years (range: 2 months- 88 years). Evaluation of the distributions of upper extremity injuries according to sex and age groups (Table 3) revealed that $70 \%$ of the patients were aged 11-35 years. This age group was followed in frequency by the 0-10 years group. The frequen- cy decreased progressively with age above 35 years. There was also a prominent male predominance among patients aged 11-35 years, who constituted the group with the highest admission rate.

The upper extremity injuries were evaluated in 6 groups according to etiology, namely, glassware cuts, falls, traffic accidents, household accidents, labor accidents, and miscellaneous injuries (e.g., stabbing and bites). While 2267 patients (33\%) were admitted with the complaints of glassware cuts, the cause of admission was falls in 1442 patients $(21 \%)$, traffic accidents in 824 patients $(12 \%)$, household accidents in 412 patients $(6 \%)$, and labor accidents in 687 patients $(10 \%)$ (Table 4).

Among the patients, $70 \%$ of those admitted with glassware cuts were aged $16-35$ years, while $54 \%$ of those admitted with falls were 21-35 years, and 22.5\% of them were aged 0-10 years. Among patients admitted due to traffic accidents, $68 \%$ were aged $16-50$ years, while $67 \%$ of those with household accidents were aged $0-10$ years, and $84 \%$ of those with labor accidents were aged 16-50 years.

Patients with self-inflicted trauma due to punching glass during a bout of aggression constituted $76 \%$ of all cases of glassware cuts. Among the patients punching glass, $84 \%$ were males, and $79 \%$ were aged $16-35$ years. Isolated skin cuts, isolated tendon cuts, fractures-dislocations, and combined injuries (blood vessel, nerve, tendon, and bone) constituted $38 \%, 27 \%$, $14 \%$, and $21 \%$ of the patients, respectively (Table 5 ). In the cases of glassware cuts, combined injuries were found in $46 \%$, and isolated tendon cuts were present in $32 \%$ of the patients. Among the patients admitted due to traffic accidents, $53 \%$ had isolated skin incisions. Isolated cutaneous incisions constituted $32 \%$ and combined incisions $31 \%$ of the patients admitted with labor accidents. While the fall cases had comparable rates of isolated skin cuts, isolated tendon cuts, and fractures, the combined injury rates were very low. While $43 \%$ of the household accidents were isolated cutaneous incisions, $28 \%$ of them were combined injuries.

The cases were studied in two groups according to the treatment being accomplished in emergency conditions or requiring secondary treatment under elective conditions. The treatments were accomplished during the initial admission in 4396 patients (64\%). These patients were also grouped according to where the treatment was undertaken, namely, those treated with local anesthesia in the emergency ward and those treated under general anesthesia in the operation theater. Surgery under general anesthesia in the operation theater was required under emergency conditions on the first admission in 187 patients $(0.37 \%)$.

Analysis of the types of injuries in the 187 patients 
operated under general anesthesia in the operation theater on first admission revealed that 64 patients (34\%) were treated for combined injuries, while 38 $(20 \%)$ required replantation, $26(14 \%)$ required fixation for serious fractures, $21(11 \%)$ required open fasciotomy, and 17 (9\%) underwent repair of major artery injuries.

Head-and-Neck injuries: The 3005 patients admitted with maxillofacial trauma constituted $28 \%$ of all patients. There were 1202 females and 1803 males, with the male:female ratio being 1.5:1.

At the time of the injuries, the mean age of patients was 23.2 (range: $1-93$ ) years. While 511 patients $(17 \%)$ were younger than 10 years, $1683(56 \%)$ were $10-35$ years, $661(22 \%)$ were $35-50$ years, and 150 $(5 \%)$ were older than 50 years (Table 6).

Traffic accidents constituted $38 \%$ of all cases with head-and-neck injuries. In the first 10 years of life, game injuries (35\%) and falls $(29 \%)$ were the most important causes of trauma. In the group aged 10-20 years, sports injuries were the most common etiology, at a rate of $30 \%$, followed in frequency by traffic accidents, at a rate of $26 \%$, and injuries during games and daily activities in $23 \%$ of the cases. Traffic accidents constituted the most frequent cause of injuries in the group aged 20-50 years. The etiologic factors were more equally distributed in the group aged over 50 years, with $27 \%$ of the patients being injured during daily activities, followed by falls, assaults, traffic accidents, and labor accidents, at rates of $23 \%, 18 \%$, $15 \%$, and $12 \%$, respectively (Table 7 ).

While $68 \%$ of the 3005 patients admitted with head-and-neck injuries had soft tissue injuries only, bone fractures were present in $32 \%$. In $41 \%$ of the 961 patients admitted with bone fractures, the fractures were accompanied by soft tissue injuries. In $21.4 \%$ of the cases, the head-and-neck injuries were accompanied by other problems such as traumas of the head, chest, abdomen, or extremities.

Fractures were present in $37.2 \%$ of the males and $24.1 \%$ of the females, while $51.8 \%$ of the traffic accidents with injuries in the head-and-neck region resulted in fractures. Furthermore, fractures occurred in $40.2 \%$ of the patients admitted due to assaults, $21.4 \%$ of the labor accidents, $18.6 \%$ of the falls, $12.3 \%$ of the sports injuries, and $11.8 \%$ of the patients injured during games and daily activities (Table 8).

While fractures were more commonly encountered in patients aged $20-50$ years, at a rate of $74 \%$, in patients aged $<10$ or $>50$ years, soft tissue injuries were prominent.

In the 961 patients with fractures, there were a total of 1883 fractures. Among these 961 patients, 67.6\%
(649 patients) had multiple and 32.4\% (312 patients) had solitary fractures.

Anatomic classification of the fractures revealed that 921 fractures $(48.9 \%)$ were located in the mandible, followed in frequency by the zygomatic bone (364 fractures, $19.3 \%$ ), base of orbit (299 fractures, 15.9\%), nose (122 fractures, 6.5\%), maxilla (113 fractures, $6 \%$ ), and frontal bone (64 fractures, 3.4\%) (Table 9).

The mandibular fractures were distributed according to fracture location as $408(44.3 \%)$ in the symphysis-parasymphysis, $236(25.6 \%)$ in the condyle, 138 $(15 \%)$ in the angulus, $102(11.1 \%)$ in the trunk, 29 $(3.1 \%)$ in the ramus, and $8(0.9 \%)$ coronoid fractures (Table 10).

Among the maxillary fractures, $45(39.8 \%)$ were in the form of Le Fort II, 43 (38\%) Le Fort I, and 17 (15\%) Le Fort III, and $8(7.2 \%)$ were sagittal fractures.

Of the 2044 patients admitted with soft tissue injuries, 91.3\% (1866 patients) were followed up after their initial treatments, while in the remaining 178 $(8.7 \%)$, fatal pathologies were controlled primarily, with the soft tissue repairs being deferred to a later date.

In the 921 patients with mandibular fractures, 63 $(6.8 \%)$ were followed without any open or closed reductions. While 512 patients $(55.6 \%)$ were treated with closed reduction, $356(38.6 \%)$ underwent open reduction and rigid fixation.

While $298(81.8 \%)$ of the zygomatic bone fractures and $258(86.2 \%)$ of the orbital fractures were treated with open reduction, the remaining cases were only followed. Among the maxillary fractures, open reduction was performed in $62(54.6 \%)$ and closed reduction in $24(21.2 \%)$ of the cases, while the remaining $27(24.2 \%)$ were followed without any intervention. Closed reduction was the mode of treatment in 115 $(94.2 \%)$ of the nasal fractures, and $35(55 \%)$ of the frontal bone fractures were followed without any intervention.

Soft tissue traumas: The 858 patients admitted with soft tissue traumas constituted $8 \%$ of all patients (Table 2). Among these patients, 323 (37.7\%) were females and the remaining $535(62.3 \%)$ were males. The mean age of the patients was 26.65 years (range: 6 months-90 years). The distributions of patients among age groups are displayed in Table 11.

Analysis of the causes of soft tissue injuries revealed that $66.2 \%$ of the cases were traffic accidents, followed in frequency by burns (19.5\%), gunshot wounds (5.6\%), falls (4.7\%), and infections (4\%). The patients admitted with infectious wounds had uncontrolled diabetes. 


\begin{tabular}{|c|c|c|c|c|c|c|}
\hline Age group & \multicolumn{2}{|c|}{ Females } & Males & \multicolumn{2}{|c|}{$\mathrm{M} / \mathrm{F}$} & Total \\
\hline $0-10$ & \multicolumn{2}{|r|}{689} & 982 & 1.3 & & 1571 \\
\hline $11-20$ & \multicolumn{2}{|c|}{555} & 1797 & 3.2 & & 2352 \\
\hline $21-35$ & \multicolumn{2}{|c|}{861} & 3695 & 4.3 & & 4556 \\
\hline $36-50$ & \multicolumn{2}{|c|}{456} & 1028 & 2.3 & & 1484 \\
\hline $51-70$ & \multicolumn{2}{|c|}{240} & 456 & 1.9 & & 696 \\
\hline \multirow{2}{*}{$\begin{array}{l}71 \uparrow \\
\text { Total }\end{array}$} & \multicolumn{2}{|c|}{29} & 44 & \multicolumn{2}{|c|}{1.5} & 73 \\
\hline & \multicolumn{2}{|c|}{2830} & 7902 & \multicolumn{2}{|c|}{2.8} & 10732 \\
\hline $\begin{array}{c}\text { Glasswa } \\
\text { cuts }\end{array}$ & Falls & $\begin{array}{c}\text { Traffic } \\
\text { accidents }\end{array}$ & $\begin{array}{c}\text { Household } \\
\text { accidents }\end{array}$ & $\begin{array}{c}\text { Labor } \\
\text { accidents }\end{array}$ & $\begin{array}{l}\text { Miscel- } \\
\text { laneous }\end{array}$ & $\begin{array}{l}\text { 1. Total } \\
\text { 1s }\end{array}$ \\
\hline $0-10$ & 325 & 75 & 278 & & 54 & 885 \\
\hline $11-15$ & 53 & 124 & 48 & 28 & 58 & 396 \\
\hline $16-20$ & 164 & 127 & 17 & 116 & 112 & 1144 \\
\hline $21-35$ & 780 & 325 & 21 & 308 & 868 & 3290 \\
\hline $36-50$ & 43 & 105 & 20 & 154 & 45 & 670 \\
\hline 130 & 77 & 68 & 28 & 81 & 100 & 484 \\
\hline 2267 & 1442 & 824 & & & 1237 & \\
\hline
\end{tabular}

\begin{tabular}{cccccccc|} 
Table 7. The distribution of etiologies among age \\
groups in head-and-neck injuries
\end{tabular}

Table 10. Distribution of the anatomic locations of mandibular fractures and frequencies (\%)

\begin{tabular}{lcc}
\hline Fracture location & Number & Percentage \\
\hline Symphysis-parasymphysis & 408 & 44.3 \\
Condyle & 236 & 25.6 \\
Angulus & 138 & 15 \\
Trunk & 102 & 11.1 \\
Ramus & 29 & 3.1 \\
Coronoid & 8 & 0.9 \\
\hline
\end{tabular}

\begin{tabular}{|c|c|c|c|c|c|c|}
\hline & Burns & $\begin{array}{c}\text { Traffic } \\
\text { accidents }\end{array}$ & Falls & $\begin{array}{l}\text { Gunshot } \\
\text { wounds }\end{array}$ & Infections & $\begin{array}{l}\text { Total } \\
\end{array}$ \\
\hline $\begin{array}{l}0-5 \\
6-15\end{array}$ & $\begin{array}{l}1928 \\
2725\end{array}$ & $\begin{array}{ll}11 & 14 \\
24 & 57\end{array}$ & $\begin{array}{l}477 \\
87\end{array}$ & $\begin{array}{ll}-2 & 2 \\
2 \quad 7\end{array}$ & $\cdots$ & $\begin{array}{c}85 \\
167\end{array}$ \\
\hline $16-35$ & 149 & $\begin{array}{ll}89 & 172\end{array}$ & 93 & 811 & & 318 \\
\hline $36-50$ & 1310 & $24 \quad 78$ & 21 & 56 & 7 & 153 \\
\hline & & & & 43 & 98 & 145 \\
\hline Total & 8186 & 182386 & 2318 & 1929 & 1816 & 858 \\
\hline
\end{tabular}

Table 16. Anatomic distribution of the lower extremity defects by frequency $(\%)$

\begin{tabular}{lcc}
\hline Fracture location & Number & Percentage \\
\hline Thigh & 46 & 7 \\
Knee & 7 & 1 \\
Crux & 197 & 30 \\
Ankle & 33 & 5 \\
Heel & 72 & 11 \\
Dorsum of the foot & 151 & 23 \\
Base of the foot & 52 & 8 \\
Combined & 97 & 15 \\
Total & 655 & 100 \\
\hline
\end{tabular}

Table 17. Anatomic distributions of the lower extremity defects according to etiology

\begin{tabular}{lcccccc}
\hline \multicolumn{7}{c}{ defects according to etiology } \\
& $\begin{array}{c}\text { Traffic } \\
\text { accidents }\end{array}$ & Burns & Falls & $\begin{array}{c}\text { Gunshot } \\
\text { wounds }\end{array}$ & Infections & Total \\
\hline Thigh & 5 & 9 & 9 & 5 & 18 & 46 \\
Knee & 4 & 2 & - & 1 & - & 7 \\
Crux & 158 & 16 & 9 & 11 & 3 & 197 \\
Ankle & 19 & 12 & - & 2 & - & 33 \\
Heel & 50 & 11 & 2 & 9 & - & 72 \\
Dorsum of foot & 131 & 13 & - & 5 & 2 & 151 \\
Base of foot & 33 & 10 & 5 & - & 4 & 52 \\
Combined & 64 & 23 & 3 & - & 7 & 97 \\
Total & 464 & 96 & 28 & 33 & 34 & 655 \\
\hline
\end{tabular}

Table 5. Classification of the pathologies according to the etiology in upper extremity injuries

Table 8. The distribution of fractures according to etiologies

\begin{tabular}{lccc}
\hline & $\begin{array}{c}\text { Number of cases } \\
\text { with fractures }\end{array}$ & $\begin{array}{c}\text { Total } \\
\text { number }\end{array}$ & Percentage \\
\hline Traffic accidents & 592 & 1142 & 51.8 \\
Assaults & 144 & 361 & 40.2 \\
Labor accidents & 51 & 238 & 21.4 \\
Falls & 61 & 329 & 18.6 \\
Sports injuries & 63 & 512 & 12.3 \\
Injuries during games & & & \\
$\quad$ daily activities & 50 & 423 & 11.8 \\
Total & 961 & 3005 & 32 \\
\hline & & & \\
\hline
\end{tabular}

Table 11. The distribution of patients admitted with soft tissue traumas by age groups

\begin{tabular}{lcccc}
\hline & Females & Males & M/F & Total \\
\hline $0-10$ & 70 & 105 & 1.50 & 175 \\
$11-20$ & 67 & 95 & 1.41 & 162 \\
$21-30$ & 64 & 98 & 1.53 & 162 \\
$31-40$ & 48 & 81 & 1.69 & 129 \\
$41-50$ & 29 & 66 & 2.27 & 95 \\
$51-60$ & 28 & 50 & 1.79 & 78 \\
$61-70$ & 21 & 29 & 1.38 & 50 \\
$70+$ & 6 & 11 & 1.83 & 17 \\
Total & 323 & 535 & 1.65 & 858 \\
\hline
\end{tabular}

Table 14. The etiologic distribution of tissue injury sites \begin{tabular}{ccc}
\hline $\begin{array}{c}\text { Traffic } \\
\text { accidents }\end{array}$ & Burns Falls $\begin{array}{c}\text { Gunshot Infections Total } \\
\text { wounds }\end{array}$ \\
\hline
\end{tabular}

\begin{tabular}{lcccccc}
\hline Lower extremities & 392 & 92 & 26 & 33 & 32 & 575 \\
Trunk & 104 & 71 & 13 & 15 & - & 203 \\
Combined & 72 & 4 & 2 & - & 2 & 80 \\
& 568 & 167 & 41 & 48 & 34 & 858
\end{tabular}

\begin{tabular}{l} 
Combined \\
Total \\
\hline
\end{tabular} 568

Table 3. Age and sex distributions of patients admitted with upper extremity injuries

\begin{tabular}{lcccc}
\hline & Females & Males & M/F & Total \\
\hline $0-10$ & 364 & 521 & 1.4 & 885 \\
$11-20$ & 238 & 1302 & 5.5 & 1540 \\
$21-35$ & 376 & 2914 & 7.8 & 3290 \\
$36-50$ & 163 & 507 & 3.1 & 670 \\
$51-70$ & 150 & 301 & 2.0 & 451 \\
$71 \uparrow$ & 14 & 19 & 1.35 & 33 \\
Total & 1305 & 5564 & 4.26 & 6869 \\
\hline
\end{tabular}

Table 6. The age and sex distributions of patients admitted with head-and-neck injuries

\begin{tabular}{lcccc}
\hline & Females & Males & $\mathrm{M} / \mathrm{F}$ & Total \\
\hline $0-10$ & 255 & 256 & 1 & 511 \\
$11-20$ & 250 & 400 & 1.60 & 650 \\
$21-30$ & 277 & 451 & 1.61 & 728 \\
$31-40$ & 250 & 357 & 1.42 & 607 \\
$41-50$ & 110 & 249 & 2.26 & 359 \\
$51-60$ & 34 & 46 & 1.35 & 80 \\
$61-70$ & 17 & 30 & 1.76 & 47 \\
$71 \uparrow$ & 9 & 14 & 1.56 & 23 \\
Total & 1202 & 1803 & 1.50 & 3005 \\
\hline
\end{tabular}

Table 9. Percentage of fractures according to anatomic locations

\begin{tabular}{lll}
\hline Fracture location & Number & Percentage
\end{tabular}

\begin{tabular}{lll}
\hline Mandible & 921 & 48.9
\end{tabular}

Zygomatic bone $\quad 364 \quad 19.3$

$\begin{array}{lll}\text { Orbit } & 299 & 15.9\end{array}$

Maxilla $\quad 113 \quad 6$

$\begin{array}{lll}\text { Nose } & 122 & 6.5\end{array}$

$\begin{array}{lll}\text { Frontal bone } & 64 & 3.4\end{array}$

\begin{tabular}{lll}
64 & 3.4 \\
\hline
\end{tabular}

Table 12. The sex distributions of the causes of soft

\begin{tabular}{lcccc}
\multicolumn{5}{c}{ tissue traumas } \\
\hline & Females & Males & M/F & Total \\
\hline Traffic accidents & 182 & 386 & 2.12 & 568 \\
Burns & 81 & 86 & 1.06 & 167 \\
Gunshot wounds & 19 & 29 & 1.53 & 48 \\
Falls & 23 & 18 & 0.78 & 41 \\
Infections & 18 & 16 & 0.89 & 34 \\
Total & 323 & 535 & 1.65 & 858 \\
\hline
\end{tabular}

Table 15. Anatomic locations of defects by frequency $(\%)$

\begin{tabular}{lcc}
\hline & Number & Percentage \\
\hline Lower extremities & 655 & 70 \\
Trunk & 283 & 30 \\
Total & 938 & 100 \\
\hline
\end{tabular}

Among the traffic accidents, $46 \%$ occurred in patients aged $16-$ 35 years, while $59 \%$ of the burns occurred in patients aged $0-15$ years, and $58 \%$ of the gunshot wounds occurred in patients aged $16-35$ years. Infectious wounds were not encountered in patients younger than 15 years, while $91 \%$ of these patients

While males constituted $68 \%$ of the cases of traffic accidents and $60 \%$ of the gunshot wound cases, the rates of infectious wounds and burns were comparable among males and females, and $56 \%$ of the patients injured due to falling were females. The sex distributions of the causes of soft tissue injuries are displayed in Table 12. with infections were older than 36 years (Table 13).

Analysis of the causes of soft tissue injuries among patient aged 0-5 years revealed that burns constituted the largest group, at a rate of $55 \%$. Among the sexes, burns occurred in females at a rate of $56 \%$ and in males at a rate of $55 \%$. 
Traffic accidents were observed at a rate of $29.4 \%$, while falls and gunshot wounds were found at rates of $13 \%$ and $2.4 \%$, respectively (Table 13 ). Traffic accidents were the most common causes of soft tissue injuries in patients aged 6-15 years, at a rate of $48.5 \%$. Males constituted $70 \%$ of the cases of traffic accidents in this age group. The second most common etiologic factor was burns, at a rate of $31 \%$.

Traffic accidents occurred at a rate of $82 \%$ among patients aged 16-35 years, and males constituted $66 \%$ of these cases (Table 13). The most common causes of soft tissue injuries in patients older than 36 years were traffic accidents (67\%) and burns (15\%) (Table 13).

Combined injuries constituted $9 \%$ of the injuries (Table 14). When the defects of patients with more than one injury were considered, there were a total of 938 defects among 858 patients, 70\% (655/938) of which were located in the lower extremities (Table 15).

Analysis of the anatomic distributions of lower extremity defects revealed that $30 \%(161 / 535)$ were located in the crux, while $23 \%(123 / 535)$ were located on the dorsum of the foot, and $12 \%(65 / 535)$ were located both in the crux and dorsum of the foot (Table 16).

The anatomic distributions of defects according to the etiologies are displayed in Table 17. In the patients admitted with lower extremity tissue defects, $34 \%(158 / 464)$ of the defects were located at the crux, and $28 \%(131 / 464)$ were located on the dorsum of the foot, while among the patients admitted with infectious wounds, $53 \%(18 / 34)$ of the defects were located in the thigh.

While 275 (42\%) of the defects were accompanied by fractures, there were no fractures in the remaining $380(58 \%)$. While $19 \%$ of the fractures were followed with immobilizer splints, $22 \%$ underwent fixation with Kirschner wires, $15.5 \%$ underwent plate-screw fixation, and $43.5 \%$ underwent external fixation. While $15.5 \%$ of the lower extremity soft tissue defects were treated with primary suturing, $4 \%$ were treated with secondary healing, 51\% required grafting, and $17 \%$ were treated with local flaps; free tissue transfer was performed in the remaining $12.5 \%$. While $62 \%$ of the tissue defects occurring in the trunk were caused by traffic accidents, $26.5 \%$ were due to burns (Table 14). Among these defects, $11 \%$ were left to secondary healing, while $24 \%$ were treated with primary suturing, $47 \%$ required grafting, and $18 \%$ were repaired with local flaps.

\section{DISCUSSION}

Trauma patients constitute the most important patient group in which a multidisciplinary approach is performed. While the trauma surgeon, neurosurgeon and orthopedist form the main team of this collabora- tion, plastic surgeons have a significant role, particularly in the treatment of an important group of patients with critical injuries. In our review of the literature regarding the practice of emergency plastic surgery, we found that the significance of plastic surgery in warand terror-related injuries was usually stressed, ${ }^{[2-4]}$ whereas no reports other than one publication with a limited number of cases ${ }^{[1]}$ were found.

Though dependent on the structure of hospitals, emergency plastic surgery has a very wide field of practice. Furthermore, patients may be referred to emergency plastic surgery particularly by general/ trauma surgeons and orthopedists as well as neurosurgeons, urologists, pediatric surgeons, ophthalmologists, otorhinolaryngologists, and obstetrics and gynecology specialists. ${ }^{[1]}$

Upper extremity injuries constitute the most common patient group of emergency plastic surgery, with an encounter frequency of $38 \%$ according to the limited data in the literature. ${ }^{[1]}$ Among the 10,732 cases admitted to our emergency outpatient clinic between 2000 and 2004, upper extremity injuries were present in $64 \%$ of the patients. Twenty-five percent of the patients admitted to emergency plastic surgery clinics had head-and-neck injuries, and 37\% had tissue defects of the lower extremities and trunk. ${ }^{[1]}$ In harmony with the literature, head-and-neck injuries were present in $28 \%$ of our patients, whereas the percentage of the patients with tissue defects, which was $8 \%$ in our cases, is considerably lower as compared with those reported in previous publications. This low rate might be due to the fact that patients with simple soft tissue injuries may also be treated in hospitals without emergency plastic surgery clinics.

As the forearm and hand have complex functions and unique anatomic structures, their injuries are commonly of combined type. ${ }^{[5]}$ In studies regarding emergency upper extremity injuries, male predominance has been found as $60-62 \%{ }^{[8,9]}$ and $82 \%,{ }^{[5]}$ while it was $81 \%$ among our cases.

In our study, the rates of labor accidents, household accidents and glassware cuts were 9.8\%, 6.3\% and $33.3 \%$, respectively. These rates greatly differ from those in a previous study of our clinic conducted between 1995 and 1997 in which emergency upper extremity injuries were investigated. In that study, the rates were $40 \%, 38 \%$ and $13 \%$ for labor accidents, household accidents and glassware cuts, respectively. ${ }^{[5]}$ This indicates that the etiologies may change over time.

Patients with self-inflicted trauma via punching through glass during a bout of aggression constituted $76 \%$ of all glassware cuts. Of these patients, $84 \%$ were males, and $79 \%$ were aged $16-35$ years. Other than the previous report of our clinic, ${ }^{[5]}$ we found no descrip- 
tion of patients with this type of self-inflicted trauma in the literature, nor was there any statistical data regarding this issue.

The rates of isolated cutaneous incisions, which we found to be $38 \%$, were close to those previously reported, as $35-45 \% .^{[5,8,9]}$ Though we found the rate of isolated tendon cuts to be $27 \%$, it has been reported to be much lower, ranging from 2 to $5 \%$ in various studies. ${ }^{[5,9]}$ In one study, it was reported that $2 \%$ of the cases with hand injuries should be referred to a clinic for treatment, and the rate of tendon incisions was reported to increase up to $29 \%$ among these cases. ${ }^{[5]}$

While the mean age of patients with head-andneck injuries was reported to range from 20-29 years in the literature, ${ }^{[10-12]}$ the mean age in our cases was 23.2, which was compatible with those of the previous reports. In the literature, female:male ratios ranging from $2: 1$ to $9: 1$ have been reported, ${ }^{[10-12]}$ whereas in our study, the male:female ratio was found to be 1.5:1.

While head-and-neck injuries were reported as most commonly occurring during games and daily activities, at a rate of $38 \%,{ }^{[11]}$ this etiologic factor was encountered at a rate of $14 \%$ in our cases. While traffic accidents were the most common causes of injury in our cases, with a rate of $38 \%$, only $12 \%$ of the headand-neck injuries in the literature were caused by traffic accidents. ${ }^{[11]}$ In the literature, traffic accidents have also been reported as being the cause in as high as $75 \%$ of the cases. ${ }^{[10]}$ Reports in which assaults were found to be the most common cause, with a rate of $48 \%$ of the cases, have also been published ${ }^{[13]}$ The rates of assaults, sport accidents, labor accidents, and falls in our study were compatible with those in the literature. ${ }^{[11]}$

While only soft tissue injuries were present in $68 \%$ of the patients with head-and-neck injuries, there were accompanying bone fractures in 961 patients (32\%). These results were similar to those in the literature. ${ }^{[11]}$ While the male:female ratio of patients with fractures has been reported to be $2.5: 1,,^{[11,12]}$ it was $2: 1$ in our study, supporting the earlier results. Other serious wounds accompany head-and-neck injuries in 10-15\% of the cases. ${ }^{[14]}$ In our study, this rate was found to be $8.7 \%$.

While the fracture was in the mandible in $48.9 \%$ of our cases, this rate shows a great variability in the literature, ranging from $24 \%$ to $75 \% \cdot{ }^{[10-13]}$ The rates of fractures elsewhere in the face in our study were compatible with those in the literature. ${ }^{[10-12]}$ In our cases, the most frequent fractures were those of the symphysis-parasymphysis, with a rate of $44.3 \%$, while they were reported to be seen at a rate of $29.3 \%$ in the literature as the second most common fractures. ${ }^{[12]}$ In various reports, the most common mandibular fracture was reported to be that of the condyle, at a rate of
$32 \%$, whereas condyle fractures were found to be the second most common fracture type in our study, with a rate of $25.3 \%$. The frequencies of other mandibular fracture types in our study were similar to those in the literature. ${ }^{[11,12]}$

Maxillofacial traumas vary in both their etiologies and the fractured facial bones, and require various treatment protocols depending on these factors. Likewise, the patients with mandible fractures were treated with closed reduction in $55.6 \%$, and with open reduction and rigid fixation in $38.6 \%$ of the cases, in harmony with the literature. ${ }^{[10-12]}$ However, $81.8 \%$ of the cases of zygomatic bone fractures and $86.2 \%$ of the cases with orbital fractures in our study were treated with open reduction, both of which were higher than the rates reported in the literature. ${ }^{[11,12]}$

While males have been reported to constitute $66 \%$ of the patients with lower extremity soft tissue injuries, males constituted $62 \%$ in our cases, supporting the literature. The mean age of patients in our study was also compatible with that in the literature. While traffic accidents were reported in the literature to be the most common cause, with a rate of $82 \%$, this rate was $62 \%$ in our cases, with traffic accidents still being the most common cause.

While males constituted $68 \%$ of the cases of traffic accidents and $60 \%$ of the cases of gunshot wounds in our study, no comparable publication in the literature with the same parameters was found. Likewise, the lower extremity defects in our study were distributed anatomically to the crux in $30 \%$, dorsum of the foot in $23 \%$, and both the crux and the dorsum of the foot in $12 \%$ of the cases; however, we failed to make any comparisons due to the scarcity of publications. ${ }^{[15]}$

Fractures were present in $42 \%$ of the cases admitted to our emergency clinic with lower extremity injuries. While $43 \%$ of these fractures were treated with external fixation, $22 \%$ underwent intramedullary fixation. These rates were comparable to the external fixation and intramedullary fixation rates previously published, as $51 \%$ and $36 \%$, respectively. ${ }^{[16]}$

Among our cases of lower extremity soft tissue defects, $51 \%$ were treated with grafting, while local flaps were used in $17 \%$, and free tissue transplantation was required in $12.5 \%$ of the cases. Although the literature is devoid of large series and the present publications are scarce, it has been reported in a few studies that these rates were $30 \%$ for repair with skin grafts, $27 \%$ for repair with local flaps, and $10 \%$ for free tissue transplantation. ${ }^{[1]}$

Traffic accidents were the cause in $62 \%$ of our cases with tissue defects of the trunk, while another $26.5 \%$ were caused by burns. Further, $47 \%$ of these defects were treated with grafts, and $18 \%$ were treated 
with local flaps. As no publication regarding patients admitted to emergency plastic surgery clinics with defects on the chest has yet been published, we were unable to make any comparisons.

Injuries requiring emergency plastic surgery interventions are usually not life-threatening unless there is a prominent hemodynamic instability due to a large vessel injury or trauma causing massive tissue damage. As a result, it is possible to complete the treatment under elective conditions in patients whose emergency situation is under control. However, complicated injuries, unless treated appropriately, may cause serious loss of function, and this may lead to considerable disability and reduced life quality. ${ }^{[6,7]}$ In the structure of various centers, there are two different rooms, namely an intervention room for plastic surgery and an operation theater. In the event there is no life-threatening situation and repair under local anesthesia is possible, many patients can be treated in the intervention room. Reports have been published stating that $67 \%$ of the patients were treated in the intervention room, while the remaining $33 \%$ were treated in the operation theater. ${ }^{[17]}$ In our series, $67 \%$ of the patients underwent treatment in the intervention room, while $1 \%$ were referred urgently to the operation theater, where their treatments were accomplished. The remaining 32\% underwent their emergency treatments in the intervention room, while their elective treatments were deferred to a later date. The causes were patient-related and circumstance-related. Coexisting serious injuries and in part social problems were the patient-related factors, while circumstance-related factors included the unavailability of the common central operation theater due to treatment of other, more fatally injured patients, since the lives of emergency plastic surgery patients are usually not threatened.

In view of the frequencies and characteristics of the treated patients, the importance and practice of plastic surgery in emergency traumatology is progressively increasing. However, particularly complicated injuries, unless appropriately treated, may lead to serious function losses and prominent disability, with reduction in life quality. We suggest that the conditions of emergency intervention rooms and operation theaters, which cannot provide immediate treatment of every patient under current conditions, should be revised according to the current situation. In addition, we suggest that this report will contribute greatly to the literature, as no extensive study in which the issues within the field of practice of emergency plastic surgery (up- per extremity surgery, head-and-neck trauma, and soft tissue traumas) has yet been published.

\section{REFERENCES}

1. Peterson SL, Moore EE. The integral role of the plastic surgeon at a level I trauma center. Plast Reconstr Surg 2003;112:1371-8.

2. Golan J, Golan E, Alder J, Sternberg N, Zagher U, Rosenberg $\mathrm{B}$, et al. Plastic surgery and civilian casualties due to "terrorist" activities. Ann Plast Surg 1982;8:359-62.

3. Cohen M, Kluger Y, Klausner J, Avital S, Shafir R. Recommended guidelines for optimal design of a plastic surgery service during mass casualty events. J Trauma 1998;45:9608.

4. Greenberg BM, Brewer BW. Avianca flight No. 052 accident: a plastic surgical perspective. Plast Reconstr Surg 1991;88:529-35.

5. Karasoy A, Sakinsel A, Gözü A, Kuran I, Baş L. Our experience in emergency hand injuries. Ulus Travma Derg 1998;4:266-9.

6. Dowrick AS, Gabbe BJ, Williamson OD. Does the presence of an upper extremity injury affect outcomes after major trauma? J Trauma 2005;58:1175-8.

7. Butcher JL, MacKenzie EJ, Cushing B, Jurkovich G, Morris J, Burgess A, et al. Long-term outcomes after lower extremity trauma. J Trauma. 1996;41:4-9.

8. Nieminen S, Nurmi M, Isberg U. Hand injuries in Finland. Scand J Plast Reconstr Surg 1981;15:57-60.

9. Angermann P, Lohmann M. Injuries to the hand and wrist. A study of 50,272 injuries. J Hand Surg Br 1993;18:642-4.

10. Al Ahmed HE, Jaber MA, Abu Fanas SH, Karas M. The pattern of maxillofacial fractures in Sharjah, United Arab Emirates: a review of 230 cases. Oral Surg Oral Med Oral Pathol Oral Radiol Endod 2004;98:166-70.

11. Gassner R, Tuli T, Hächl O, Rudisch A, Ulmer H. Craniomaxillofacial trauma: a 10 year review of 9,543 cases with 21,067 injuries. J Craniomaxillofac Surg 2003;31:51-61.

12. Motamedi MH. An assessment of maxillofacial fractures: a 5-year study of 237 patients. J Oral Maxillofac Surg 2003;61:61-4.

13. Kelley P, Crawford M, Higuera S, Hollier LH. Two hundred ninety-four consecutive facial fractures in an urban trauma center: lessons learned. Plast Reconstr Surg 2005;116:42e$49 \mathrm{e}$.

14. Hogg NJ, Stewart TC, Armstrong JE, Girotti MJ. Epidemiology of maxillofacial injuries at trauma hospitals in Ontario, Canada, between 1992 and 1997. J Trauma 2000;49:425-32.

15. Suri M, Patel A, Vora H, Raibagkar S, at al. Post-traumatic posterior heel soft tissue defect reconstruction. Indian J Plastic Surg 2005;38:138-42.

16. Pinsolle V, Reau AF, Pelissier P, Martin D, Baudet J. Softtissue reconstruction of the distal lower leg and foot: are free flaps the only choice? Review of 215 cases. J Plast Reconstr Aesthet Surg 2006;59:912-8.

17. Anandan SM, Agrawal K, Panda K. The major role of a minor plastic surgery operation theater. Ann Plast Surg 2006;56:703-4. 